\title{
Outdoor air quality data analysis of Al-Mansoriah residential area (Kuwait): air quality indices results
}

\author{
S. A. Al-Haider ${ }^{1} \&$ S. M. Al-Salem ${ }^{2}$ \\ ${ }^{1}$ Applied Sciences Department, College of Technological Studies, \\ Public Authority for Applied Education and Training, PO Box: 14561, \\ Al-Faiha 70700, State of Kuwait \\ ${ }^{2}$ Petrochemical Processes Program Element, Petroleum Research and \\ Studies Center, Kuwait Institute for Scientific Research, PO Box: 24885, \\ Safat 13109, State of Kuwait
}

\begin{abstract}
Environmental awareness is of growing concern in the state of Kuwait, especially after the recognition of Kuwait Environment Public Authority (KUEPA) as a separate entity with legal power back in 2001. In this communication, the outdoor air quality data collected over the period of five years (2000-2004) were analyzed for Al-Mansoriah residential area in AlAsemah "Capital" Governorate (Kuwait). Data points were in two different time spans; five minute original data points and hourly mean averages. Air Quality Indices (AQI) based on the following pollutants: $\mathrm{SO}_{2}, \mathrm{CO}, \mathrm{O}_{3}$ and $\mathrm{NO}_{2}$ were calculated. Based on $\mathrm{CO}$ and $\mathrm{SO}_{2}$, the $\mathrm{AQI}$ was determined "good" ranging between an annual mean of 0.06-0.15. Based on ground level ozone and nitrogen dioxide AQI resulted in the "moderate" category for the period of study.
\end{abstract}

Keywords: $\mathrm{KUEPA}, \mathrm{SO}_{2}, \mathrm{CO}, \mathrm{O}_{3}, \mathrm{NO}_{2}, \mathrm{AQI}$.

\section{Introduction}

Many Gulf Council Countries (GCC) suffer from air pollution health effects especially when it comes to respiratory system chronic diseases and cancers associated with such airborne pollutants [1]. Kuwait is no exception, being a petroleum industry oriented country. Many pollution sources are linked with the 
downstream/upstream industry in the state but yet still little action is taken by the concerned parties. One way of monitoring such pollution levels is what has become a standard approach of Air Quality Indices (AQI) calculation. Each Air Quality Index is a standardized indicator of the air quality in a given location. It measures mainly ground-level ozone and particulates (except the pollen count), but may also include sulphur dioxide, and nitrogen dioxide. Various agencies around the world measure such indices, though definitions may vary between places. In the US, EPA calculates the AQI for five major air pollutants regulated by the Clean Air Act: ground-level ozone, particle pollution (also known as particulate matter), carbon monoxide, sulfur dioxide, and nitrogen dioxide. For each of these pollutants, EPA has established national air quality standards to protect public health. Ground-level ozone and airborne particles are the two pollutants that pose the greatest threat to human health in US.

Many scientists have devoted their work towards air pollution monitoring and standardizing rules and regulations governing cities around the world. This could be determined by literature available regarding the matter. An air quality monitoring methodology was presented by Landulfo et al. [2], by employing an elastic backscattering Lidar, sunphotometer data, air quality indexing and meteorological data in the city of São Paulo, Brazil, a typical Urban Area. This procedure was made aiming to gather information from different optical atmospheric techniques and add this information to the air quality data provided regularly by the environmental agencies in the city. The parameters obtained by the Lidar system, such as planetary boundary layer height, aerosol optical thickness and aerosol extinction and backscattering aerosol coefficients are correlated with air quality indexes/reports provided by state environmental control agencies in order to extend the database information concerning pollution assessment and abate policies.

In India [3], the measured $24 \mathrm{~h}$ average criteria pollutants such as sulfur dioxide, oxides of nitrogen, respirable suspended particulate matter and suspended particulate matter for the period from 1997 to 2005 at three air quality monitoring stations were used for the development of AQIs. The results indicated that the air pollution at all the three air quality monitoring stations can be characterized as 'good' and 'moderate' for $\mathrm{SO}_{2}$ and $\mathrm{NO}_{x}$ concentrations for all days from 1997 to 2004. The Pollution Standards Index (PSI) was initially established in response to a dramatic increase in the number of people suffering respiratory irritation due to the deteriorating air quality. The PSI was subsequently revised and implemented by the USEPA in 1999, and became known as the (AQI) that includes data relating to particle suspension, $\mathrm{PM}_{2.5}$, and a selective options of either 8-hour or 1-hour ozone concentration during increased $\mathrm{O}_{3}$ periods. This was discussed in the publication of Cheng et al. [4]. An aggregate AQI based on the combined effects of five criteria pollutants (CO, $\mathrm{SO}_{2}, \mathrm{NO}_{2}, \mathrm{O}_{3}$ and $\mathrm{PM}_{10}$ ) taking into account the European standards was developed previously [5]. An evaluation was carried out for each monitoring station and for the whole area of Athens, Greece. A comparison was made with a modified version of Environmental Protection Agency/USA (USEPA) maximum value AQI model adjusted for European conditions. Hourly data of air pollutants 
from 4 monitoring stations, available during 1983-1999, were analyzed for the development of the proposed index.

The objective of this communication is to investigate the ambient air quality of Al-Mansoriah residential area using standard AQI calculations with respect to four airborne pollutants. These pollutants are: sulfur dioxide $\left(\mathrm{SO}_{2}\right)$, carbon monoxide $(\mathrm{CO})$, ground level ozone $\left(\mathrm{O}_{3}\right)$ and nitrogen dioxide $\left(\mathrm{NO}_{2}\right)$. No previous attempts (to the authors knowledge) have been initiated or published regarding this matter in Kuwait.

\section{Investigated area description}

Al-Mansoriah residential area hosts Kuwaiti residents of $\mathrm{mid} / \mathrm{high}$ class and could be considered a posh area. Fig.1 shows the area from satellite imagery, indicating main locations including Al-Arabi sports club, Cairo St. and receptor point (i.e. area's polyclinic).

The receptor point of the area was the polyclinic of Al-Mansoriah situated near the area's Co-Op, which associated with restaurant and human related pollution emissions. These pollutants include $\mathrm{n}-\mathrm{CH}_{4}$ (resulting from restaurants), NOx and CO (emissions of automobile and other burning sources) and VOCs from the gas and gasoline dispensing station. On the other hand, Al-Arabi sports

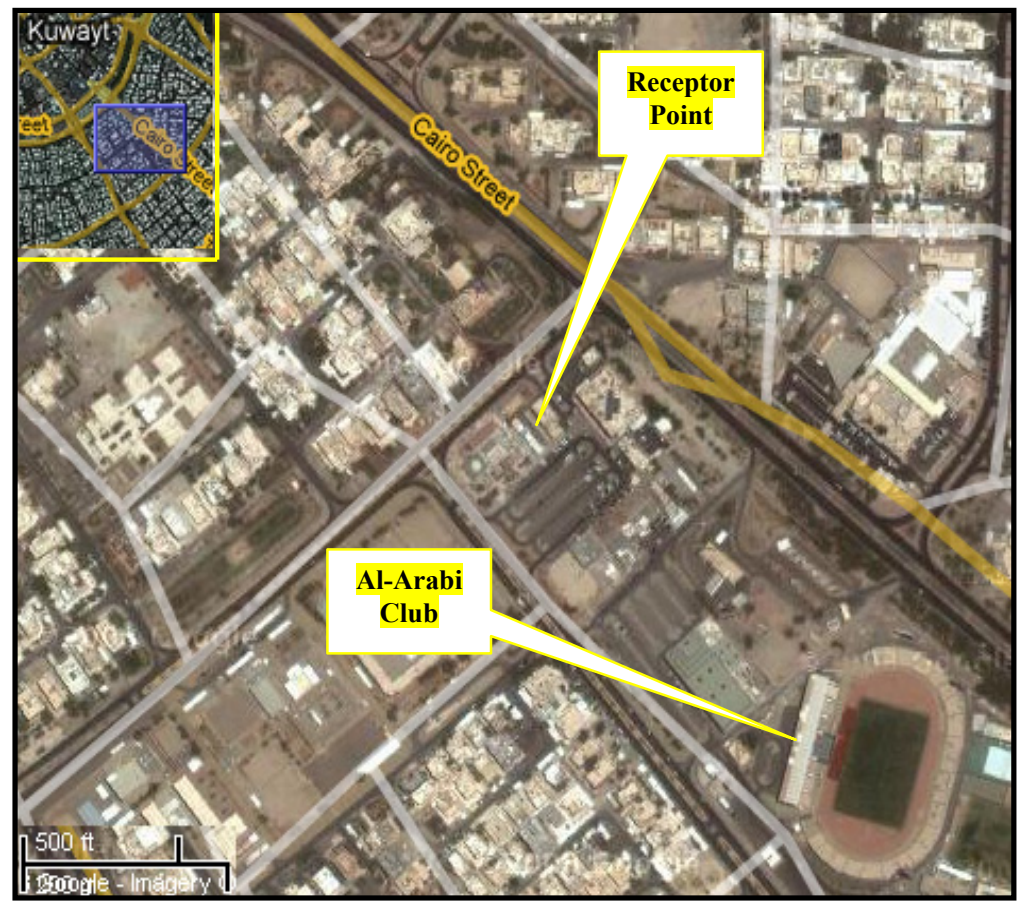

Figure 1: Al-Mansoriah residential area adapted from Google earth imagery. Main area locations are indicated. 
club is considered one of the largest sports and family functions facility in Kuwait, in terms of children entertainment lounges and other function spaces. All of these sections in the club are always adjacent to a food court or lounges which also emit gases through vents and other outlets.

Cairo St. is situated to the north side of the receptor point. It is one of the busiest streets of Kuwait especially when it comes to school time linking three main residential areas together in the governorate, i.e. Al-Mansoriah, AlQadisiah and Al-Daeiah. Automobile vehicles operated with gasoline are the main source of pollution associated with it. Rush hours are usually between 7:30 am to 9:00 am (weekdays); and 8:00 pm to 9:30 pm (weekends).

\section{Data collection and methods}

The data used in this study were secured form the Kuwait Environment Public Authority (KUEPA), more precisely Al-Mansoriah monitoring station covering the period from Jan $1^{\text {st }} 2000-$ Dec $31^{\text {st }} 2004$. The station is operated with a number of air sampling devices and analyzers with a tolerance of $1 \%$. Air probe was approximately $15 \mathrm{~m}$ above sea level. All data were stored and manipulated with EnviDas data acquisition software which did store up to three months worth of data points. Pollutants collected by the station included the following: $\mathrm{CH}_{4}$ (ppm), n-MHC (ppm), $\mathrm{CO}$ (ppm), $\mathrm{CO}_{2}$ (ppm), $\mathrm{NO}$ (ppb), $\mathrm{NO}_{2}$ (ppb), NOx (ppb), VOCs (ppb), mp-Xylenes (ppb), $\mathrm{NH}_{3}$ (ppb), $\mathrm{H}_{2} \mathrm{~S}$ (ppb) and $\mathrm{O}_{3}$ (ppb). Metrological conditions were collected via a fixed weathering station recording the following: wind speed $\left(\mathrm{ms}^{-1}\right)$ and direction $\left({ }^{0}\right)$, relative humidity $(\%)$ and ambient temperature $\left({ }^{\circ} \mathrm{C}\right)$.

Data points were treated and filtered before performing any analysis. Filtration procedure was performed as indicated by [6-11]. $\mathrm{NOx}, \mathrm{NO}_{2}$ and $\mathrm{NO}$ points exceeding $200 \mathrm{ppb}$ were deleted from the spreadsheets, in order to eliminate any automobile point source effect on data collection. $\mathrm{CH}_{4}$ levels below $1.3 \mathrm{ppm}$ were also deleted to avoid ion presence and instrumentation chocking points. Calibration and span check points were also deleted.

The AQIs were calculated using standards USEPA methodology. The purpose of the AQI is to help you understand what local air quality means to health. To make it easier to understand, the AQI is divided into six categories (Table 1).

Table 1: $\quad$ Air Quality Index (AQI) category in accordance with the USEPA.

\begin{tabular}{|c|c|c|}
\hline AQI Value Range & AQI Conditions & Audience Color \\
\hline 0 to 50 & Good & Green \\
51 to 100 & Moderate & Yellow \\
101 to 150 & Unhealthy for Sensitive & Orange \\
151 to 200 & Groups & Red \\
201 to 300 & Unhealthy & Purple \\
301 to 500 & Very Unhealthy & Maroon \\
& Hazardous & \\
\hline
\end{tabular}


The AQI is calculated every hour for each air quality parameter using the formulas indicated below (Table 2). The highest number calculated for a specific hour is used as the AQI for that hour. Four pollutants were chosen to be studied which were: $\mathrm{SO}_{2}, \mathrm{CO}, \mathrm{NO}_{2}$ and $\mathrm{O}_{3}$.

Table 2: $\quad$ Air Quality Index (AQI) Calculation formulas in accordance to the USEPA.

\begin{tabular}{|c|c|c|c|}
\hline Parameter Name & Concentration & Units & Formula \\
\hline \multirow{3}{*}{ Carbon Monoxide } & If $<=13$ & ppm & $\mathrm{AQI}=1.92 \times$ Concentration \\
\hline & If $>13$ & ppm & $\mathrm{AQI}=(1.47 \times$ Concentration $)+5.88$ \\
\hline & If $<=0.05$ & ppm & $\mathrm{AQI}=500 \times$ Concentration \\
\hline \multirow[t]{2}{*}{$\mathrm{O}_{3}$} & $\begin{array}{c}\text { If }>.05<= \\
0.08\end{array}$ & ppm & $\mathrm{AQI}=(833 \times$ Concentration $)-16.67$ \\
\hline & If $>0.08$ & ppm & $\mathrm{AQI}=(714 \times$ Concentration $)-7.14$ \\
\hline $\mathrm{SO}_{2}$ & All & ppm & $\mathrm{AQI}=147.06 \times$ Concentration \\
\hline & If $<=0.21$ & ppm & $\mathrm{AQI}=238.09 \times$ Concentration \\
\hline Nitrogen Dioxide & If $>0.21$ & ppm & $\begin{array}{c}\mathrm{AQI}=(156.24 \times \text { Concentration })+ \\
17.19\end{array}$ \\
\hline $\mathrm{PM}_{2.5}$ & $\begin{array}{l}\text { If }<=30 \\
\text { If }>30\end{array}$ & $\begin{array}{l}\mathrm{ugm}^{-3} \\
\mathrm{ug} / \mathrm{m}^{-3}\end{array}$ & $\begin{array}{c}\mathrm{AQI}=0.8333 \times \text { Concentration } \\
\mathrm{AQI}=(0.5 \times \text { Concentration })+10\end{array}$ \\
\hline
\end{tabular}

\section{Results and discussion}

Based on the standard USEPA methodology the AQIs of the pollutants $\mathrm{SO}_{2}, \mathrm{CO}$, $\mathrm{NO}_{2}$ and $\mathrm{O}_{3}$, were calculated. Table 3 shows the results obtained by the running calculations of AQI for the five years period based on yearly averages.

In terms of $\mathrm{SO}_{2}$ and $\mathrm{CO}$, good air quality resulted from the calculations based on the standards calculations and annual mean. Both pollutants recorded a minimum in the last two years of study (2003 and 2004). Maximum $\mathrm{SO}_{2} \mathrm{AQI}$ calculated was in the year 2002 recording an AQI of 71.77. In terms of $\mathrm{NO}_{2}$, moderate air quality was characterized for Al-Mansoriah with a maximum value for the first year of study of 160.46. Moderate air quality is also characterized for $\mathrm{O}_{3}$ in the period of study.

Fig.2 shows the scatter left by the points of average AQI vs. years of study. A clear increase in the CO AQI, when comparing the 2000 (AQI=6.8) and 2004 $(\mathrm{AQI}=14.2)$ values. $\mathrm{AQI}$ of $\mathrm{CO}$ has increased by more than $100 \%$ in the period of study. In terms of ground level ozone $\left(\mathrm{O}_{3}\right)$, there was a general decrease in the annual average trend. Unlike the case of $\mathrm{SO}_{2}$, where there was a general decrease but a shooting off point does exist in the middle range. $\mathrm{NO}_{2}$ had also a general decrease in the trend. AQI in 2000 was equal to 37.46 while in 2004 it was 31.8. 
Table 3: $\quad$ Air Quality Index (AQI) calculated for Al-Mansoriah residential area in the time of the study (2000-2004).

\begin{tabular}{|c|c|c|c|c|c|}
\hline Year & Pollutant & Avg. AQI & Min. AQI & Max. AQI & Category \\
\hline \multirow{5}{*}{2000} & $\mathrm{SO}_{2}$ & 1.84 & 0.15 & 47.06 & Good \\
& $\mathrm{CO}$ & 6.80 & 0.06 & 26.53 & Good \\
& $\mathrm{NO}_{2}$ & 37.46 & 0.24 & 160.46 & Moderate \\
& $\mathrm{O}_{3}$ & 37.72 & 0.50 & 391.99 & Moderate \\
\hline \multirow{5}{*}{2001} & $\mathrm{SO}_{2}$ & 2.73 & 0.15 & 37.94 & Good \\
& $\mathrm{CO}$ & 1.93 & 0.06 & 17.53 & Good \\
& $\mathrm{NO}_{2}$ & 31.40 & 0.24 & 133.75 & Moderate \\
& $\mathrm{O}_{3}$ & 38.26 & 1.0 & 84.24 & Moderate \\
\hline \multirow{5}{*}{2002} & $\mathrm{SO}_{2}$ & 3.97 & 0.147 & 71.77 & Good \\
& $\mathrm{CO}^{*}$ & 18.52 & 0.50 & 25.0 & Good \\
& $\mathrm{NO}_{2}$ & 37.45 & 0.23 & 168.58 & Moderate \\
& $\mathrm{O}_{3}$ & 36.56 & 0.50 & 80.65 & Moderate \\
\hline \multirow{5}{*}{2003} & $\mathrm{SO}_{2}$ & 4.9 & 0.1 & 68.2 & Good \\
& $\mathrm{CO}^{*}$ & 14.85 & 0.1 & 27.6 & Good \\
& $\mathrm{NO}_{2}$ & 34.6 & 0.2 & 105.9 & Moderate \\
& $\mathrm{O}_{3}$ & 33.31 & 0.5 & 65 & Moderate \\
\hline \multirow{6}{*}{2004} & $\mathrm{SO}_{2}$ & 3.2 & 0.1 & 52.2 & Good \\
& $\mathrm{CO}^{*}$ & 14.2 & 0.1 & 27.6 & Good \\
& $\mathrm{NO}_{2}$ & 31.8 & 0.5 & 93.6 & Moderate \\
& $\mathrm{O}_{3}$ & 33.10 & 0.5 & 79.3 & Moderate \\
\hline
\end{tabular}

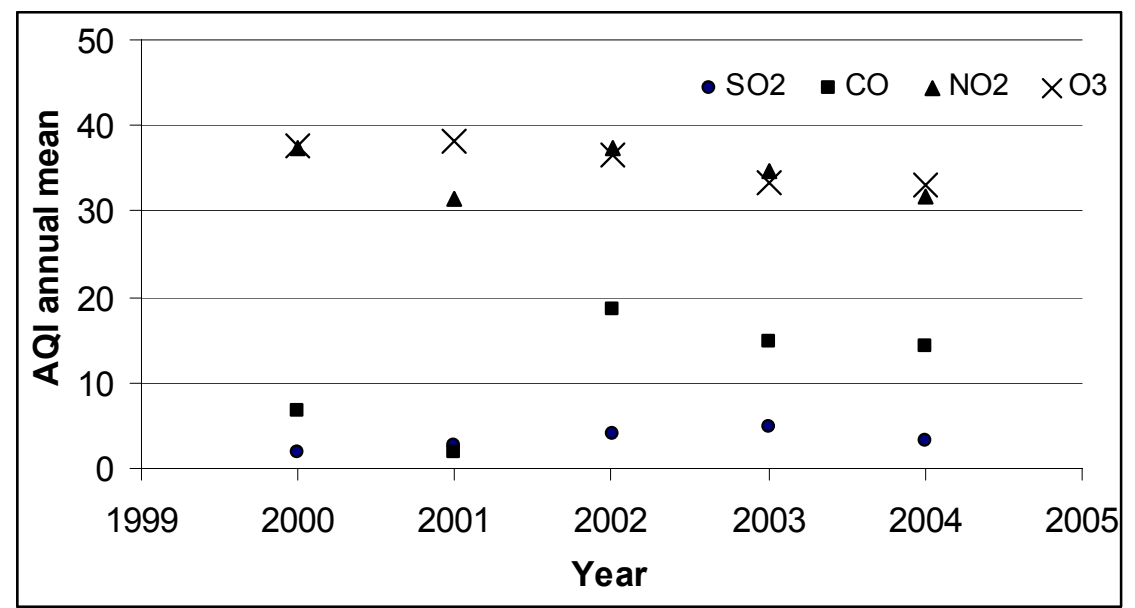

Figure 2: Average Air Quality Index for the studied pollutants in the period of study. 


\section{Conclusion}

A general decrease was witnessed in the $\mathrm{AQI}$ values along the period of study. The four pollutants studied (i.e. $\mathrm{SO}_{2}, \mathrm{CO}, \mathrm{NO}_{2}$ and $\mathrm{O}_{3}$ ) resulted in a "good" and "moderate" ambient air quality. This leads to the understanding that AlMansoriah residential area exhibited a moderate air quality during the five years of investigation. In terms of $\mathrm{SO}_{2}$ and $\mathrm{CO}$, both pollutants recorded a minimum in the last two years of study (2003 and 2004). Maximum $\mathrm{SO}_{2}$ AQI calculated was in the year 2002 recording an $\mathrm{AQI}$ of 71.77. For $\mathrm{NO}_{2}$, moderate air quality was characterized for Al-Mansoriah with a maximum value for the first year of study of 160.46. Moderate air quality is also characterized for $\mathrm{O}_{3}$ in the period of study. A clear increase in the CO AQI, when comparing the $2000(\mathrm{AQI}=6.8)$ and 2004 (AQI=14.2) values. AQI of CO has increased by more than $100 \%$ in the period of study. KUEPA has no records of any AQI running investigation in their current plan. More strict regulations should be applied for monitored area in the state of Kuwait.

\section{Acknowledgements}

Both authors would like to thank the KUEPA for providing the dataset used for this study. Gratitude and thanks must be given to everyone who supported this work, especially Dr. A.R. Khan (EUD/KISR) for his magnificent encouragement.

\section{References}

[1] Al-Salem, S.M. and Bouhamrah, W.S., Ambient concentrations of benzene and other VOCs at typical industrial sites in Kuwait and their cancer risk assessment, Res J Chem Environ, 10(3), pp. 42-46, 2006.

[2] Landulfo, E., Matos, C.A., Torres, A.S., Sawamura, P. and Uehara, S.T., Air quality assessment using a multi-instrument approach and air quality indexing in an urban area, Atm Res, 85(1), pp. 98-111, 2007.

[3] Shiva Nagendra, S.M., Venugopal, K. and Jones, S.L., Assessment of air quality near traffic intersections in Bangalore city using air quality indices, Trans Res Part D: Transport and Environment, 12(3), pp. 167-176, 2007.

[4] Cheng, W.L., Chen, Y.S., Zhang, J., Lyons, T.J., Pai, J.L., Chang, S.H., Comparison of the Revised Air Quality Index with the PSI and AQI indices, Sci Total Environ, 382(2-3), pp. 191-198, 2007.

[5] Kyrkilis, G., Chaloulakou, A. and Kassomenos, P.A., Development of an aggregate Air Quality Index for an urban Mediterranean agglomeration: Relation to potential health effects, Environ Int, 33(5), pp. 670-676, 2007.

[6] Al-Salem, S. and Al-Fadhlee, A., Ambient levels of primary and secondary pollutants in a residential area: population risk and hazard index calculation over a three years study period, Am J Environ Sci, 3(4), pp. 244-228, 2007.

[7] Al-Salem, S.M. and Al-Haddad, A.A., Pollutants monitoring and source determining: Effect of oil refineries on a residential area, In: Proc $2^{\text {nd }}$ Int 
Con on Scientific Computing to Computational Engineering, Edited By: Prof. Demos T. Tsahalis, Set No: 960-530-080-X, Athens, Greece, $5^{\text {th }}-8^{\text {th }}$ July, 2006.

[8] Al-Salem, S.M. and Khan, A.R., Methane dispersion modeling and source determination around urban areas in Kuwait, In: Proc $1^{\text {st }}$ Int Con \& Exhib Green Industry, Manama, Bahrain, 20 ${ }^{\text {th }}-22^{\text {nd }}$ November, 2006.

[9] Al-Salem, S.M., Al-Haddad, A.A. and Khan, A.R., Primary pollutants monitoring and modeling using chemical mass balance (CMB) around Fahaheel residential area, Am J Environ Sci, 4(1), pp. 13-21, 2008.

[10] Khan, A. and Al-Salem, S., Primary and secondary pollutants monitoring around an urban area in the state of Kuwait: a three years study, $\operatorname{Res} J$ Chem Environ, 11(3), pp. 77-81, 2007.

[11] Khan, A. and Al-Salem, S., Seasonal variation effect on airborne pollutants in an urban area of the state of Kuwait, J Environ Res Dev, 1(3), pp. 215$218,2007$. 